This manuscript is contextually identical with the following published paper:

Fekete R., Nagy T., Bódis J., Biró É., LÖKi V., Süveges K., TAKÁcs A., TÖKÖlyi J., MoLNÁR V. A. (2017): Roadside verges as habitats of rare lizard-orchids (Himantoglossum spp.): ecological traps or refuges? - Science of the Total Environment 607-608: 1001-1008. http://dx.doi.org/10.1016/j.scitotenv.2017.07.037 
Science of the Total Environment 607-608: 1001-1008., $2017 \quad$ Research paper

Réka Fekete $^{\mathrm{a}}$, Timea Nagy ${ }^{\mathrm{b}}$, Judit Bódis ${ }^{\mathrm{b}}$, Éva Biró ${ }^{\mathrm{b}}$, Viktor Löki $^{\mathrm{a}}$, Kristóf Süveges ${ }^{\mathrm{a}}$, Attila Takács ${ }^{\mathrm{a}, \mathrm{c}}$, Jácint Tökölyi ${ }^{\mathrm{d}}$, Attila Molnár V. ${ }^{\mathrm{a}, \mathrm{c} *}$

\section{Roadside verges as habitats for endangered lizard-orchids (Himantoglossum spp.): ecological traps or refuges?}

a Department of Botany, University of Debrecen, Egyetem tér 1, H-4032 Debrecen, Hungary

b Department of Plant Sciences and Biotechnology, University of Pannonia, Georgikon Faculty, Festetics u. 7., H-8360 Keszthely, Hungary

c MTA-DE 'Lendület' Evolutionary Phylogenomics Research Group, University of Debrecen, Debrecen Egyetem tér 1., H-4032 Hungary

d MTA-DE Behavioural Ecology Research Group, University of Debrecen, Debrecen, Egyetem tér 1., H-4032 Hungary

* Corresponding author at Department of Botany, University of Debrecen, Egyetem tér 1, H4032 Debrecen, Hungary

E-mail address: mva@science.unideb.hu (A. Molnár V.).

\section{ABSTRACT}

Alterations in traditional land use practices have led to severe declines in the area of seminatural grasslands, thereby seriously threatening plant and animal species dependent on these habitats. Small anthropogenic managed habitats, like roadsides can act as refuges and might play an important role in conserving these species. Colonization of roadside verges by endangered lizard orchids (Himantoglossum spp.) has long been known, but few studies have systematically explored the suitability of roadside habitats for these orchids and the impact of roads on them. In this paper we present results of targeted surveys of three lizard orchid taxa on roadsides from eight European countries. During these surveys we searched for lizard orchids inhabiting roadside verges and recorded their distance from road, aspects of the roadside environment, as well as vegetative and reproductive characteristics of individual plants. We found large numbers of lizard orchids on roadside verges. Distance from roads was not uniformly distributed: orchids occurred more closely to roads than expected by chance. 
This suggests that regular management of roadsides (e.g. mowing) might enhance colonization and survival of lizard orchids. On the other hand, we also found that close proximity to roads negatively affects reproductive success, suggesting that the immediate vicinity of roads might act as an ecological trap (i.e. favourable in terms of colonization and survival but unfavourable in terms of reproduction). Nonetheless, the fact that significant and viable populations are maintained at roadsides suggest that traditionally managed roadside verges may allow long-term persistence of lizard orchid populations and may serve as refuges in a landscape context.

Keywords: Calcareous dry grasslands, Ecotone, Mowing, Orchidaceae, Reproductive success, Secondary habitats.

\section{HiGHLIGHTS}

- We surveyed endangered lizard orchids on roadside verges in 8 European countries

- We found large number of individuals, implying importance of roadsides as habitats

- Individuals occurred significantly closer to the roads than expected by chance

- Distance from road did not affect stem height and number of flowers

- In close proximity to roads, reproductive success was reduced 


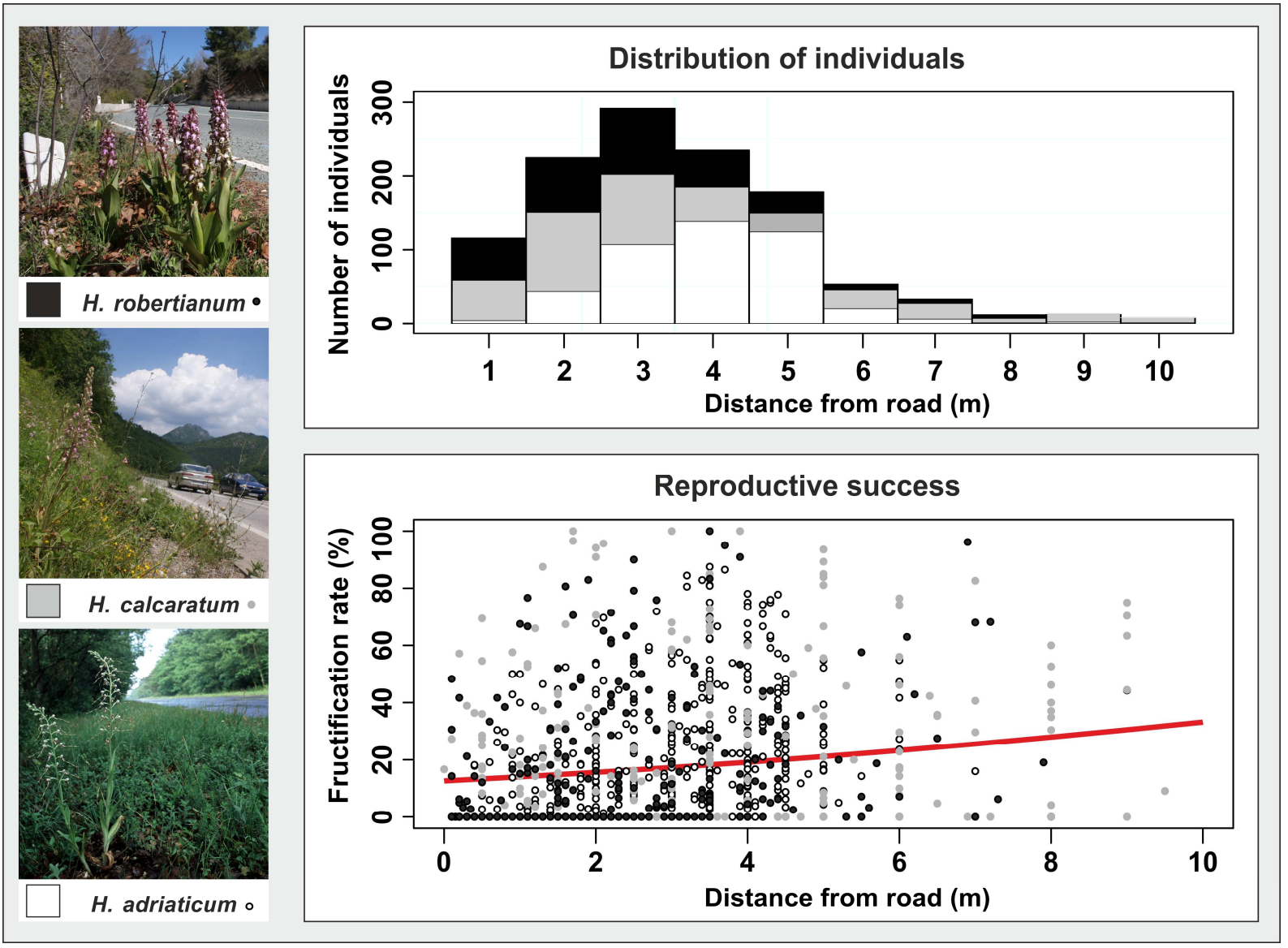

\section{Introduction}

Semi-natural habitats host a large number of threathened plant species, but are declining throughout the world due to habitat destruction and fragmentation (Tikka et al., 2000; Tilman et al., 2001; Nascimbene et al., 2016), intensification of agricultural land use (Krauss et al., 2010) and abandonment of traditional agricultural practices (Bignal and McCracken, 1996). Plants inhabiting semi-natural grasslands tolerate, or even prefer traditional land use practises (grazing and mowing; Eriksson et al., 2002; Pykälä et al., 2005), which are quickly disappearing with the development of modern technologies. For plant species sensitive to alterations in land use, small anthropogenic, managed habitats such as midfield islets, river dikes, kurgans or roadsides could play an important role in the maintenance of plant species richness by serving as refuges in a landscape context (Perring, 1969; Way, 1970; Harrington, 1994; Allem, 1997; Godefroid, 1999; Cousins, 2006; Bátori et al., 2016; Deák et al. 2016a, 2016b). Appropriate management of road verges allows existence of valuable grassland communities maintaining rare species, thus may have a significant conservation value (Hovd and Skogen, 2005; Auestad et al., 2011). 
Roadside vegetation can contribute to the conservation of the flora when the original ecosystem has been destroyed (Vasconcelos et al., 2014). Roadsides, or verges, are often the only remnants of native vegetation remaining, and are important sources of biodiversity in the landscape in parts of Australia, The Netherlands and Norway where the surrounding land cover has been extensively transformed (Hussey, 1999; Deckers et al., 2005; Hovd and Skogen, 2005; Coffin, 2007). In the United Kingdom, for instance, almost half of the native plant species can be found on roadside verges (Way, 1977). Regularly mowed roadside verges serve as refuges for a highly cut-tolerant, endangered grassland species, Gentianella campestris in Finland (Huhta and Rautio, 2007).

Roadside verges can create special habitat conditions, e.g. due to the runoff water, which leads to increased level of moisture and soil mineral content that helps the vegetative and reproductive growth of plants (Lamont et al., 1991, 1994a, 1994b). Furthermore, roadsides can serve as ecological corridors for plant dispersal, linking distant habitat patches (Tikka et al., 2001). Moreover, the dispersal of small seeds can be facilitated by the air turbulence of cars (Ross, 1986) or by the mud attached to the vehicles, which often contain large number of seeds, especially when the roadside vegetation is well developed (Clifford, 1959).

The roadside environment, however, can also harm the vegetation in multiple ways. (1) Pollutants emitted by vehicles may accumulate in the soil and in plants (Ndiokwere, 1984). (2) Dust may exacerbate secondary stresses, such as sensitivity to drought, insects and pathogens, and it may alter the competitive balance of the community (Farmer, 1993). (3) Road construction and maintenace regimes, such as the introduced soil used during construction may contain seeds and can lead to the spread of alien species (Greenberg et al., 1997). (4) De-icing salt increases salinity in the soil, which can cause osmotic stress by altering the $\mathrm{pH}$, nutrient availability and nutrient balance of the soil, ultimately leading to changes in species composition of the roadside vegetation (Davison, 1971; Tikka et al., 2001). Additionally, bare grounds formed due to the deposition of nitrogen derived from roadside management lead to increased cover of salt tolerant and ruderal species at roadside verges (Truscott et al., 2005). (5) Herbicides used in road management may threaten seminatural roadside vegetation (Watson et al., 1989). (6) Roads generally have a negative effect on the occurence and diversity of insects (pollinators of entomophilous orchids). The reason is that the mortality of insects increases due to pollutants emitted by vehicles or collision with cars, while traffic noise affects the behaviour of insects and they often avoid roads (Muñoz et al., 2014). Hence, reproductive success of roadside populations may be lower due to absence or 
decreased abundance of pollinators. (7) Roads increase the probability that showy flowers (such as orchids) will be collected by tourists (Ballantyne and Pickering, 2011).

Colonization of orchids on roadside verges (Federici and Serpieri, 1868; Turrill, 1932; Good, 1936) or other anthropogenically strongly influenced habitats (Ratcliffe, 1974; Greenwood and Gemmell, 1978; Davis, 1979; Holliday and Johnson, 1979; Kelcey, 1984; Box, 1999; Jurkiewicz et al., 2001; Grant and Koch 2003; Esfeld et al., 2008; Shefferson et al, 2008; Bzdon 2009; Lundholm and Richardson 2010; Woch et al., 2013, Löki et al., 2015; Molnár V. et al., 2017) or naturally highly disturbed habitats (e.g. landslides, Neto et al., 2017) is a well known phenomenon. Roadside verges are similar to natural habitats of orchids in many respects (e.g. lack of dominant species, low tree/shrub cover, etc.), while microscopic seeds allow orchids to colonize newly created habitat patches along roads via long distance seed dispersal by wind (Arditti and Ghani, 2000; Jersáková and Malinová, 2007; Sonkoly et al., 2016). One of the most characteristic representatives of European orchids colonizing roadsides are members of genus Himantoglossum (lizard orchids). The genus contains 12 species (Sramkó et al., 2014; Bateman et al., 2017), most of them are rare and occur on dry calcareous grasslands. Himantoglossum adriaticum and $H$. calcaratum subsp. jankae (formerly ' $H$. caprinum') are also listed by Annex II of the EU Habitats Directive 92/43/EEC (European Union, 1992) on the conservation of natural habitats, wild fauna and flora. These two species are of great community interest and their habitat conservation is particularly important. Given that orchids greatly rely on their pollinators and mycorrhizal fungi (Waterman and Bidartondo, 2008), they are also indicators of biodiversity (Swarts and Dixon, 2009). Populations living on roadside verges from at least 7 Himantoglossum taxa in 17 countries are known (Table 1). A conspicuous example is Himantoglossum hircinum in France, where several thousands of individuals have been observed on roadside verges between Paris and Bordeaux (Good, 1936), often mentioned as a 'roadside weed' growing on a wide range of neutral to basic substrates including concrete debris (Carey and Farrel, 2002). In England, among the 201 localities of the species registered between 1641 and 2002, 17 (7\%) are found at roadsides (Carey and Farrel, 2002). H. adriaticum was first found in 1867 along the road south and west of Urbino in Italy (Federici and Serpieri, 1868). Recently, in Urbino province 10 out of 32 occurrences of this species were on roadside banks (Klaver, 2011). In Bulgaria more than $50 \%$ of the most numerous population of Himantoglossum calcaratum subsp. jankae (formerly 'H. caprinum') is found on roadsides (Zahariev, 2014).

Table 1 
Occurrences on roadside verges of 7 Himantoglossum taxa based on literature data and personal observations by the authors (signed with an asterisk).

\begin{tabular}{ll}
\hline Species & Countries [Source] \\
\hline H. adriaticum Baumann & Croatia*, Hungary*, Italy* [Federici and Serpieri, \\
& 1868; Klaver, 2011] \\
H. calcaratum (G. Beck) Schlechter & Bosnia and Herzegovina*, Montenegro*, Serbia* \\
subsp. calcaratum & (incl. Kosovo) \\
H. calcaratum (G. Beck) Schlechter & Albania* [Turrill, 1932], Bulgaria* [Zahariev, 2014], \\
subsp. jankae (Somlyay, Kreutz \& & Greece*, Hungary*, Montenegro*, Slovakia*, \\
Óvári) Bateman, Molnár \& Sramkó & Turkey* \\
H. caprinum (M-Bieb.) Spreng. & Turkey* \\
H. comperianum (Steven) P.Delforge & Greece (Lesvos)*, Turkey* \\
H. hircinum (L.) Sprengel & Belgium [Godefroid, 1999], France* [Good, 1936; \\
& Carey and Farrel, 2002], Germany [Ehmke, 2005], \\
& Switzerland [Känzig-Schoch, 2006], UK [Carey and \\
& Farrel, 2002] \\
H. robertianum (Loiseleur) P. & Cyprus*, Greece (incl. archipelago)*, France*, Italy \\
Delforge & (incl. archipelago)*, Turkey* \\
\hline
\end{tabular}

Together, these observations suggest that roadsides can be important habitats for Himantoglossum orchids. However, it is unclear how proximity to roads affects their occurrence and reproductive success. Our aims in this paper were to (1) systematically survey the occurrence of lizard orchids along paved roads across Europe; (2) investigate how proximity to roads might impact occurrence, reproductive traits and reproductive success of plants. We predicted that, due to the above mentioned negative effects of roads on plants, orchids will occur farther from roads than expected by chance; furthermore, flowering stem height, number of flowers and reproductive success will be lower in plants closest to the roads. Given that these fitness-related traits might depend on a number of ecological factors, we recorded and controlled for characteristics of the roadside environment of lizard orchids: altitude, exposition (Northern, Western, Southern, Eastern exposition or horizontal surface) and the tree/shrub cover above the verges. These factors might affect orchid reproductive traits and/or reproductive success through their effect on the general climatic conditions (altitude), water availability (sloping surfaces are expected to have lower water availability 
because of the greater draining of water; Bochet and García-Fayos, 2004) or sunlight exposure (exposition and tree/shrub cover).

\section{Material and methods}

\subsection{Field work}

We studied 3 lizard orchid taxa [Himantoglossum adriaticum H. Baumann, H. calcaratum (G. Beck) Schlechter subsp. calcaratum, Himantoglossum robertianum (Loisel.) P. Delforge] on verges of paved roads (covered by asphalt) established on calcareous substrates in 8 countries (Fig. 1, Table S1 in Appendix A). Field sampling campaigns were made in Bosnia and Herzegovina (6-7 July 2013, 13-14 July 2014, 6-7 July 2015); Croatia (6-7 June 2014); Cyprus (11-22 March 2016,16-19 May 2016); France (26-30 April 2016); Hungary (15-25 June 2013, 3-18 June 2014, 19 June - 8 July 2015); Italy (10-14 July 2015); Montenegro (56 July 2015) and Serbia (29 June - 2 July 2015, 1-6 September 2016).

The geocoordinates and the altitude of the visited localities were determined by a Garmin ETrex Legend GPS handheld device recorded in WGS84 format. For each individual found, we measured its absolute distance from the road. Because the width of roadside verges was not uniform, we also expressed distance from the road relative to the available habitat (i.e. the width of the roadside verge). We measured the width of roadside verge using Google Earth Pro software (within each population it was defined as the longest distance between the road edge and the beginning point of a different type of vegetation, e.g. forest, crop field etc.). The relative distance of an individual was the ratio of its absolute distance from the road and the width of the roadside verge. This measure takes into account the fact that not all verges are of the same width and hence it is not always possible to be located far away from the road. 


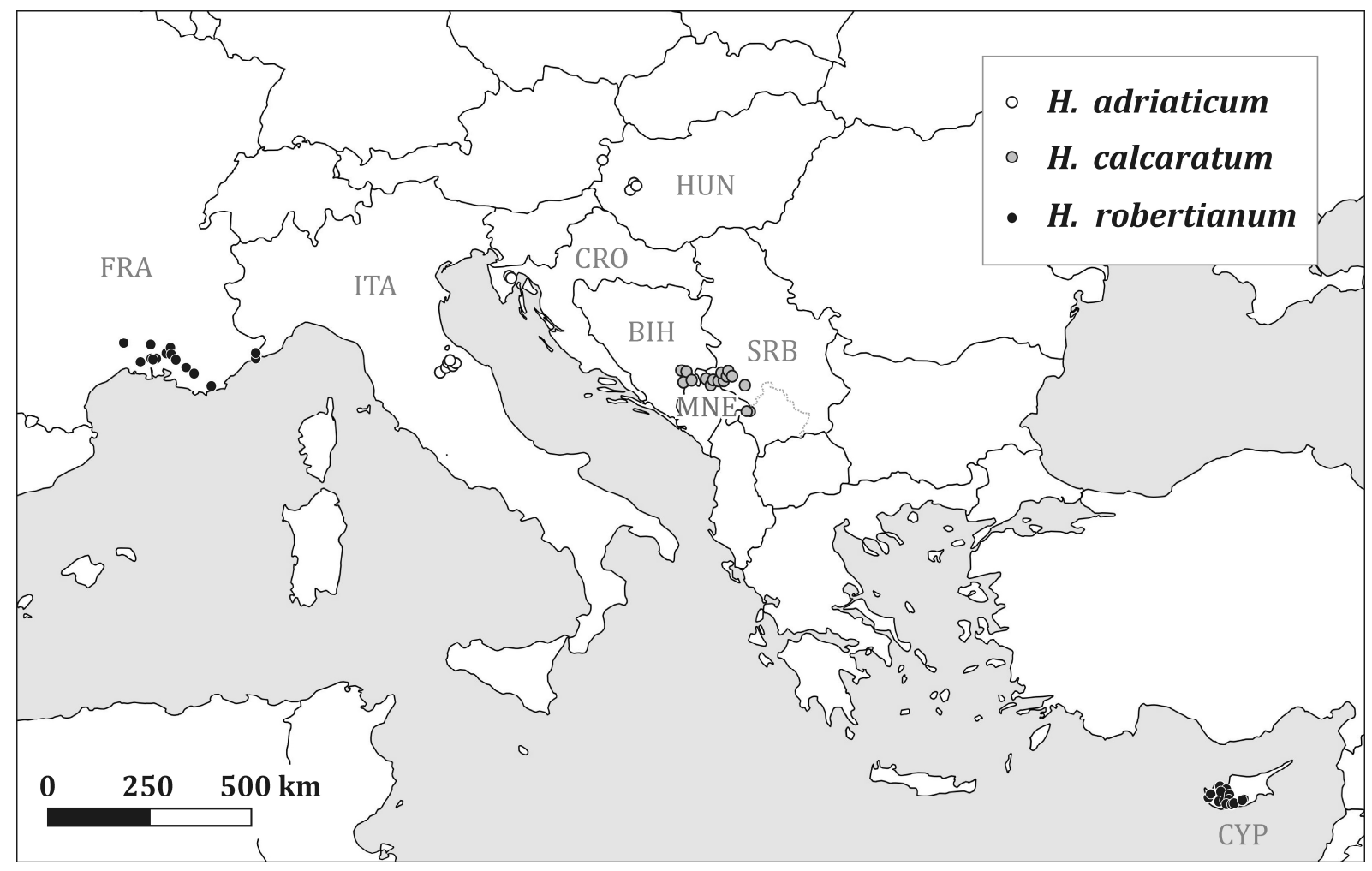

Fig. 1. The locations of the study sites. Abbreviations: CRO - Croatia, ITA - Italy, HUN Hungary, MNE - Montenegro, SRB - Serbia, BIH - Bosnia and Herzegovina, CYP - Cyprus, FRA - France.

To characterize individual condition of plants we measured the height of flowering stem and the number of flowers. Reproductive success was quantified as the number of fruits divided by the total number of flowers (fructification rate, hereafter FR). Since not all individuals were in fruiting stage, FR was measured only for individuals that already had fruits and/or withered flowers.

We recorded whether the plant was on flat or sloping surface, and in the latter case, the exposition of the slopes. We created a discrete variable from these data, which contained the following 5 categories: flat position, Northern, Eastern, Southern or Western exposition.We estimated the cover of shrub and tree layer in $1 \times 1$ meter quadrats above each individual.

\subsection{Data analyses}

Statistical analyses were carried out in the R statistical environment (R Core Team, 2016). First, we used simple descriptive statistics to describe the basic features of habitats (altitude, distance from road, tree/shrub cover) for each species separately. Medians were used in these cases due to non-normal distribution of data. Second, we used One-sample Kolmogorov- 
Smirnov test to evaluate whether the absolute and relative distance of individual plants from the road follows a uniform distribution. This test was performed for the three species separately.

Third, we tested how road proximity and other habitat characteristics affect reproductive characteristics and reproductive success of individual orchids. For this we used mixed-effect statistical models where the number of flowers, stem height and fructification rate were used as dependent variables in separate models. Number of flowers was a count variable and we used Generalized Linear Mixed Models (GLMM) with Poisson distribution. Fructification rate was analyzed using binomial GLMMs with number of fruits and number of flowers without fruits as a bivariate response variable. Stem height was normally distributed and we used Linear Mixed-Effects Models (LMM) in this case. Explanatory variables were altitude, exposition, distance from road, stem height and tree/shrub cover (\%). In all three models, species and site ID were included as random factors, to take into account the fact that individuals within a species or those recorded at the same site are not independent data points (they are likely to be more similar to each other than expected by chance). Furthermore, by including species and site ID as random factors we statistically control for variation between sites and species, thereby focusing on variation within sites / species and its connection to differences in the explanatory variables (proximity to roads and other habitat characteristics). An individual-level random effect was also added to the models analyzing fructification rate, to take into account overdispersion in the response variable (Harrison, 2014). In all three cases we started by building full models containing all explanatory variables. This was followed by model simplification: non-significant predictors were removed from the models in a stepwise manner (based on the largest p-values) until minimally adequate models were obtained (containing only variables with a statistically significant effect). Likelihood Ratio Tests were performed after each model simplification step.

\section{Results}

\subsection{Number of individuals found and characteristics of roadside habitats}

We found altogether 1167 Himantoglossum indviduals, from which 446 belonged to $H$. adriaticum, 398 to $H$. calcaratum and 323 to H. robertianum. 58 sampling sites were found near country roads, 19 populations near highways, 3 populations near European routes and a single occurrence was found close to a motorway parking road (Table S1). Roadside habitats of lizard orchids were found between $22 \mathrm{~m}$ and $1291 \mathrm{~m}$ altitude above sea level. Width of the roadside verges was between 1.1 and $10 \mathrm{~m}$ (median $9.5 \mathrm{~m}$ ), and absolute road distance of 
Himantoglossum individuals varied between $0 \mathrm{~m}$ and $9.5 \mathrm{~m}$, with a median of $2.5 \mathrm{~m}$. Tree/shrub cover above Himantoglossum individuals varied between $0 \%$ and 100\%, but most orchids occured at lower tree/shrub cover (median 5\%).

\subsection{Distance from roads}

Mean absolute distance of individuals from road was $2.6 \pm 1.7 \mathrm{~m}$, while relative distance was $30 \pm 20 \%$. The occurence of individuals with regard to absolute and relative road distance differed significantly from a hypothetical uniform distribution in the case of all three species (Table 2, Fig. $2 \& 3$ ).

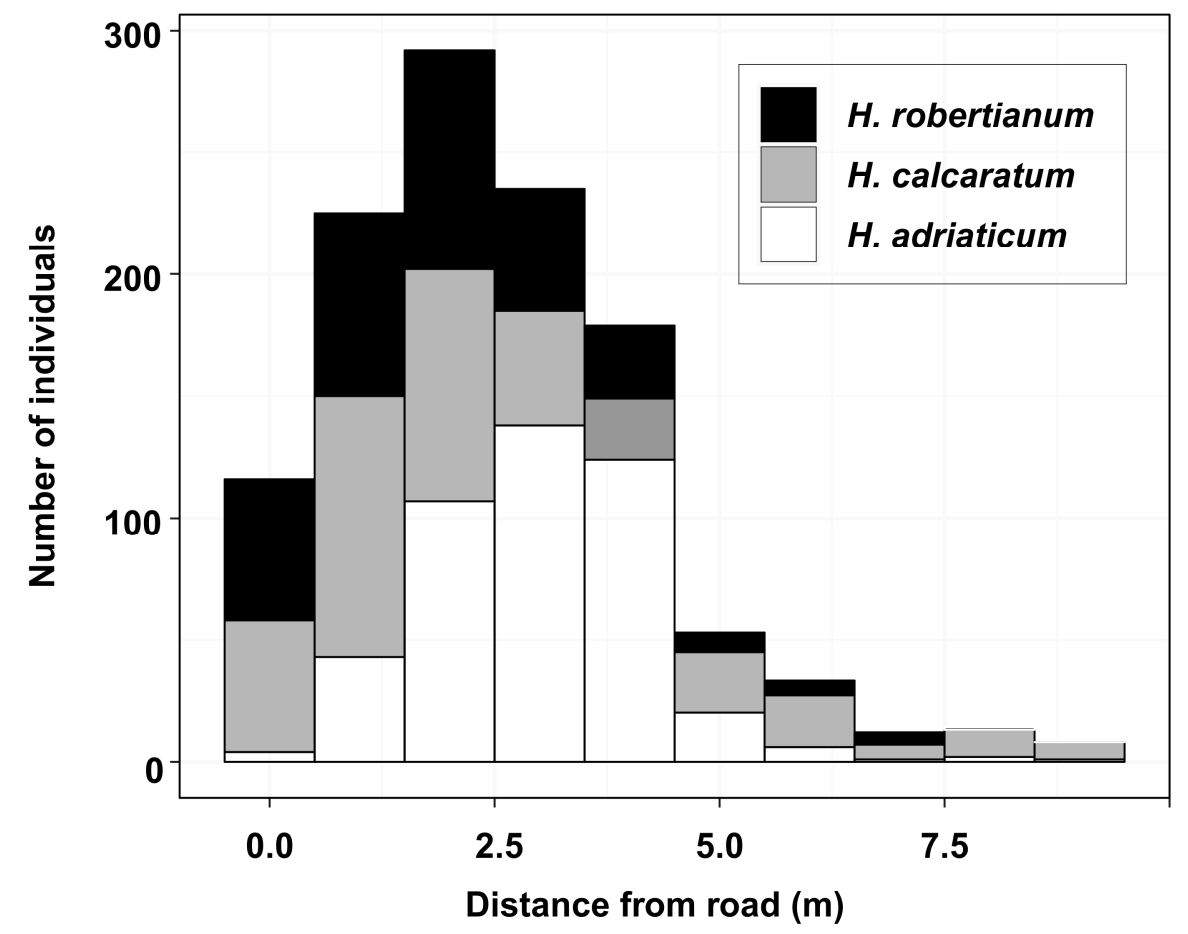

Fig. 2. Absolute distance from road of individuals of the three Himantoglossum species studied. 


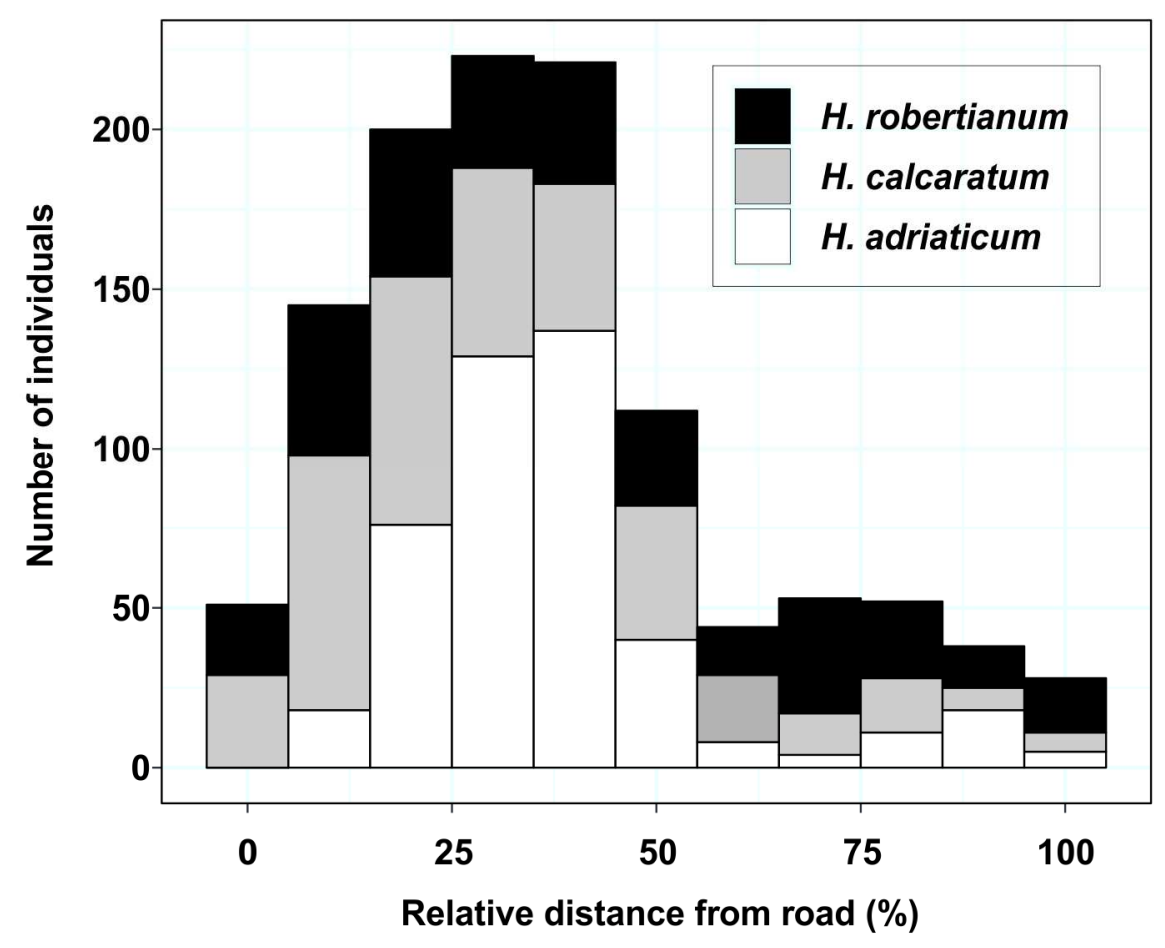

Fig. 3. Relative distance from road of individuals of the three Himantoglossum species studied.

\section{Table 2}

Mean absolute and relative distances from the road of the three Himantoglossum species. Pvalues originate from One-sample Kolmogorov-Smirnov-tests.

\begin{tabular}{lcccc}
\hline \multicolumn{1}{c}{ Species } & $\begin{array}{c}\text { Mean } \pm \text { SD of absolute } \\
\text { distance }(\mathrm{m})\end{array}$ & p-value & $\begin{array}{c}\text { Mean } \pm \text { SD of relative } \\
\text { distance }(\%)\end{array}$ & p-value \\
\hline H. adriaticum & $3.1 \pm 1.2$ & $<0.001$ & $39 \pm 17$ & $<0.001$ \\
H. calcaratum & $2.6 \pm 2.1$ & $<0.001$ & $32 \pm 24$ & $<0.001$ \\
H. robertianum & $2.1 \pm 1.6$ & $<0.001$ & $42 \pm 28$ & $<0.001$ \\
\hline
\end{tabular}

\subsection{Height and number of flowers of Himantoglossum individuals}

The mean \pm SD number of flowers for all species combined was 28.48 \pm 13.06 (H. adriaticum: $31.26 \pm 14.25$, H. calcaratum: $24.97 \pm 11.09$, H. robertianum: $29.13 \pm 12.79)$. Distance from road had no effect on the number of flowers. The number of flowers was significantly positively related to stem height and negatively to tree/shrub cover in the minimal model (Table 3). Altitude and exposition had no effect and dropped out during model simplification. 


\section{Table 3}

Full and minimal models (Poisson GLMM) showing predictors with a significant effect on the number of flowers.

\begin{tabular}{llccccccc}
\hline & \multicolumn{3}{c}{ Full model } & \multicolumn{5}{c}{ Minimal model } \\
& Estimate & SE & $\begin{array}{c}\mathrm{t}- \\
\text { value }\end{array}$ & $\begin{array}{c}\mathrm{p}- \\
\text { value }\end{array}$ & Estimate & SE & $\begin{array}{c}\text { t- } \\
\text { value }\end{array}$ & $\begin{array}{c}\text { p- } \\
\text { value }\end{array}$ \\
\hline (Intercept) & 3.346 & 0.104 & 32.16 & $<0.001$ & 3.336 & 0.106 & 31.36 & $<0.001$ \\
\hline Altitude & -0.002 & 0.020 & -0.10 & 0.922 & & & & \\
\hline Stem height & 0.329 & 0.007 & 45.67 & $<0.001$ & 0.331 & 0.007 & 46.71 & $<0.001$ \\
\hline Exposition & & & & & & & & \\
\hline \multicolumn{1}{c}{ Northern } & -0.018 & 0.021 & -0.84 & 0.401 & & & & \\
\hline \multicolumn{1}{c}{ Eastern } & -0.041 & 0.020 & -2.06 & 0.040 & & & & \\
\hline \multicolumn{1}{c}{ Southern } & -0.002 & 0.023 & -0.10 & 0.921 & & & & \\
\hline \multicolumn{1}{c}{ Western } & -0.033 & 0.022 & -1.48 & 0.138 & & & & \\
\hline Tree/shrub cover & -0.028 & 0.007 & -4.30 & $<0.001$ & -0.029 & 0.006 & -4.47 & $<0.001$ \\
\hline $\begin{array}{l}\text { Distance from } \\
\text { road }\end{array}$ & -0.013 & 0.007 & -1.75 & 0.080 & & & & \\
\hline
\end{tabular}

The mean \pm SD stem height for all species combined was $50.12 \pm 17.05 \mathrm{~cm}$ (H. adriaticum: $55.18 \pm 16.86 \mathrm{~cm}, H$. calcaratum: $56.29 \pm 17.26 \mathrm{~cm}, H$. robertianum: $37.22 \pm 10.16 \mathrm{~cm}$ ). Distance from road had no effect on stem height in the minimal model. We found a significant positive effect of tree/shrub cover on stem height. Furthermore, exposition had a significant effect on stem height (plants were shorter on Northern, Eastern and Western slopes compared to individuals on non-sloping surfaces, while plants on Southern slopes did not differ significantly from individuals on non-sloping surfaces) (Table 4). Altitude had no significant effect on stem height.

\section{Table 4}

Full and minimal models (LMM) showing predictors with a significant effect on stem height. Note that for LMMs significance is determined based on the absolute t-value: parameters with $|t|>2$ are considered significant at the 0.05 level.

\begin{tabular}{lcccccc} 
& \multicolumn{3}{c}{ Full model } & \multicolumn{3}{c}{ Minimal model } \\
\hline Intercept & Estimate & SE & t-value & Estimate & SE & t-value \\
Altitude & 3.880 & 0.132 & 29.341 & 3.879 & 0.131 & 29.519 \\
Exposition & 0.003 & 0.023 & 0.120 & & & \\
$\quad$ & & & & & & \\
$\quad$ Northern & -0.116 & 0.030 & -3.819 & -0.116 & 0.030 & -3.839 \\
$\quad$ Eastern & -0.109 & 0.030 & -3.692 & -0.108 & 0.029 & -3.691 \\
$\quad$ Southern & -0.035 & 0.032 & -1.092 & -0.034 & 0.032 & -1.058
\end{tabular}




\begin{tabular}{lllllll} 
Western & -0.110 & 0.031 & -3.583 & -0.110 & 0.030 & -3.650 \\
Tree/shrub cover & 0.052 & 0.009 & 5.531 & 0.052 & 0.009 & 5.540 \\
Distance from road & 0.004 & 0.010 & 0.412 & & & \\
\hline
\end{tabular}

\subsection{Reproductive success}

Reproductive success was measured for 805 individuals. The mean \pm SD FR for all species combined was $25.28 \pm 23.71 \%$ (H. adriaticum: $21.78 \pm 21.14 \%$, H. calcaratum: $33.95 \pm 26.66$ $\%$, H. robertianum: $25.89 \pm 24.71 \%)$.

Distance from road had a significant positive effect on FR in the minimal model (Fig. 3). Stem height was likewise positively related to FR. Tree/shrub cover had a significant negative effect on FR. Altitude and exposition had no significant effect on reproductive success (Table 5). The effects of road on reproductive success were corroborated on the species level analysis in case of $H$. adriaticum (Table S2) and H. robertianum (Table S4) but not in H. calcaratum (Table S3).

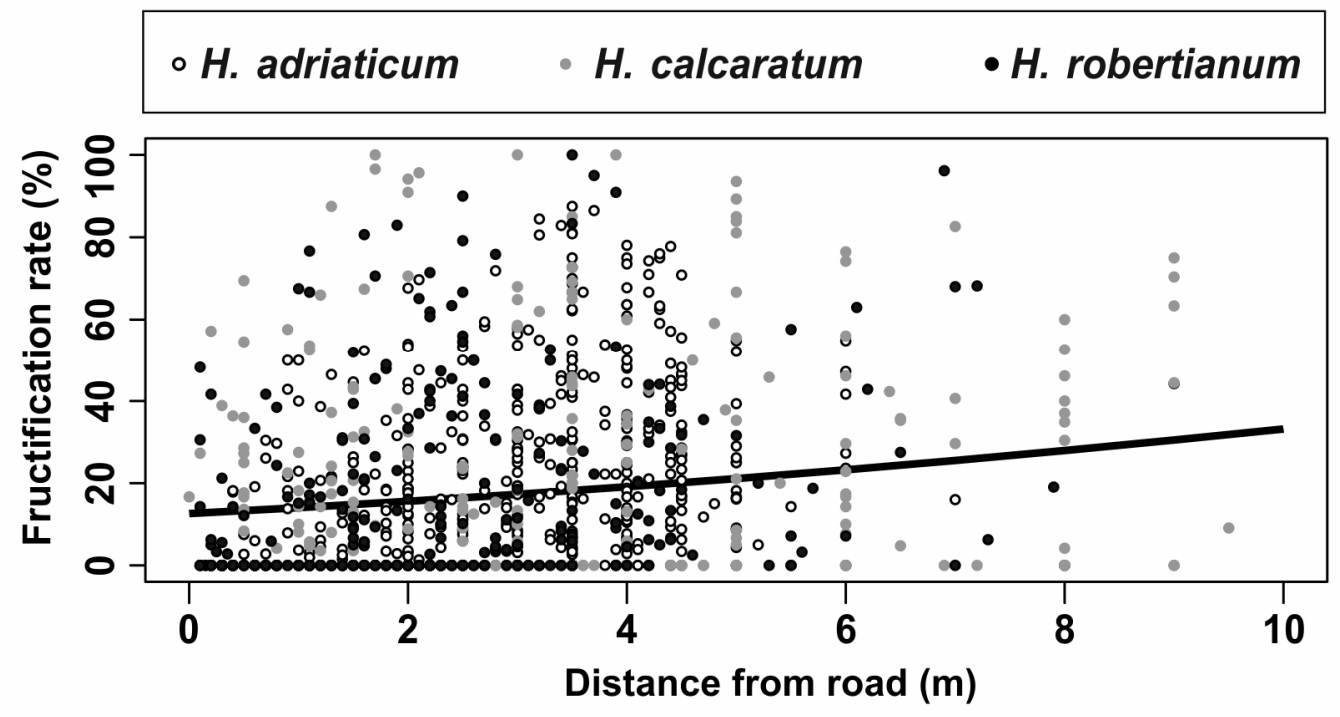

Fig. 3. Relationship between fructification rate of individuals of the three Himantoglossum species and their distance from road. 


\section{Table 5}

Full and minimal models (binomial GLMM) showing significant predictors of FR.

\begin{tabular}{|c|c|c|c|c|c|c|c|c|}
\hline & \multicolumn{4}{|c|}{ Full model } & \multicolumn{4}{|c|}{ Minimal model } \\
\hline & Estimate & SE & $\begin{array}{l}\mathrm{t}- \\
\text { value }\end{array}$ & $\mathrm{p}$-value & Estimate & SE & $\begin{array}{l}\text { t- } \\
\text { value }\end{array}$ & $\mathrm{p}$-value \\
\hline \multicolumn{9}{|l|}{ Distance } \\
\hline from road & 0.232 & 0.065 & 3.562 & $<0.001$ & 0.236 & 0.063 & 3.735 & $<0.001$ \\
\hline Altitude & 0.118 & 0.174 & 0.676 & 0.499 & & & & \\
\hline Stem height & 0.394 & 0.068 & 5.820 & $<0.001$ & 0.38622 & 0.066 & 5.846 & $<0.001$ \\
\hline \multicolumn{9}{|l|}{ Exposition } \\
\hline Northern & 0.120 & 0.185 & 0.648 & 0.517 & & & & \\
\hline Eastern & 0.394 & 0.173 & 2.272 & 0.023 & & & & \\
\hline Southern & 0.159 & 0.205 & 0.775 & 0.438 & & & & \\
\hline Western & 0.042 & 0.211 & 0.198 & 0.843 & & & & \\
\hline Tree/shrub & & & - & & & & - & $<0.001$ \\
\hline cover & -0.422 & 0.059 & 7.099 & $<0.001$ & -0.441 & 0.059 & 7.515 & \\
\hline
\end{tabular}

\section{Discussion}

In this study, we described the occurrence of three endangered orchid taxa in a little-studied anthropogenic habitat (roadside verges) across eight European countries. Roadside verges are narrow grassland fragments and act as ecotones (representing mainly transitions from grasslands to forest edges). Due to their weak competitive ability, orchids are frequently found in transitional, ecotone habitats, such as mesoxeric scrubland patches and forest edges (Bray and Wilson, 1992; Rai et al., 2010; Duchon 2012; Djordjević et al., 2016; Slaviero et al., 2016). Our data suggest that roadsides are suitable habitats for lizard orchids and could serve as refuges for these plants.

Roadsides are habitats with high disturbance and fragmentation, which may negatively affect genetic diversity (Young et al., 1996) or reproductive success of plants due to reduced pollen delivery, reduced quality of the pollen, or lack of pollinators in small populations (e.g, Jennersten, 1988; Lamont et al., 1993). Because of these factors, roadsides are often considered suboptimal habitats of low conservation value. However, previous studies showed evidence for the occurence of several endangered orchid species at roadsides such as, Anacamptis collina, A. laxiflora, A. longicornu, A. pyramidalis, Neottia ovata, Ophrys apifera, O. bertolonii, O. bombylifora, O. speculum, O. sphegodes, O. tenthredinifera (Brandes, 1988, 1998a, 1998b), Spiranthes hongkongensis, Zeuxine strateumatica (Sun, 1997), Anacamptis morio (Smith and Cross, 2016), and Ophrys apifera (Gardiner and Vaughan, 2009). Furthermore, a previous study investigating a rare shrub species (Grevillea 
barklyana) showed that, although roadside populations were usually small and isolated, there was no significant difference in genetic variability between roadside and natural populations (Hogbin et al., 1998). Therefore, these habitats could have substantial conservation value.

Not only were lizard orchids present on roadside verges in high numbers, they seemed to occur more closely to roads than expected by chance. This observation is in line with previous results by Zahariev (2014) who showed that in roadside populations of Himantoglossum calcaratum subsp. jankae (formerly ' $H$. caprinum') in Bulgaria, individuals occur at high frequency on the edge of asphalt roads. Close proximity to roads might be beneficial for orchids because the vegetation here is usually less closed, contains fewer infrastructural obstacles and is less likely to be overgrazed. Furthermore, the immediate vicinity of roads is regularly mowed as part of road management and mowing has repeatedly been demonstrated to have a positive effects on orchids in other habitat types (Curtis, 1946; Janečková et al., 2006; Sletvold et al., 2010; Smith and Cross, 2016). Hence, regular mowing of roadsides could play a key role in orchid colonization and survival.

While roadsides appear to be suitable habitats for Himantoglossum orchids, we also found that close proximity to roads negatively affects their reproductive success, since the proportion of flowers bearing fruits increased with distance from the road. This phenomenon might be caused by several independent factors. On the one hand, reduced vegetative and reproductive growth of plants induced by dust (Farmer 1993) and increased amount of heavy metals (Saikkonen et al., 1998, Ryser and Sauder, 2006) in the soil were documented. On the other hand, proximity to roads might have a negative effect on the occurrence and diversity of insects due pollutants emitted by vehicles, increased mortality due to collision with cars and noise which leads to road avoidance (Muñoz et al., 2014, Kallionemi et al., 2017). These collective effects may contribute to reduced fructification rate in the immediate vicinity of roads. Himantoglossum taxa have been studied only tangentially for their pollinator spectra (surveyed by Claessens and Kleynen, 2011). Flowers of all studied Himantoglossum species are pollinated by members of hymenopteran family Apidae. The early flowering $H$. robertianum is pollinated mainly by large-sized social bees, e.g. Bombus lucorum, B. terrestris and Xylocopa violacea. Honeybees (Apis mellifera) might play an important role in the pollination of $H$. adriaticum (Biró et al., 2015), in addition to bee species belonging to the genera Andrena, Bombus, Colletes, Lasioglossum and Osmia. Pollinators of H. calcaratum subsp. calcaratum are insufficiently known; during field work in Bosnia and Herzegovina we observed only honeybees as visitors of the charactersitic, long-spured flowers. Roadside verges provide valuable habitats for bees (Hopwood 2008, Heneberg, et al. 2017) and this 
might positively influence reproduction of Himantoglossum populations living near roads. However abundance of pollinators at roadside verges is decreasing with distance to natural and semi-natural habitats (Jakobsson and Ågren, 2014). and is strongly influenced by quality, spatial and temporal distribution of flower resources within the landscape (Kallionemi et al. 2017). Other factors, such as overall traffic could further influence pollinator availability. While previous studies failed to find a relationship between traffic load and bee abundance (Hopwood 2008), it remains to be shown whether this lack of association holds in the immedite vicinity of roads as well (this is where traffic could have the greatest negative effects). If heavy traffic is detrimental to pollinators in the immediate vicinity of roads, this might explain why the reproductive success of Balkanic $H$. calcaratum populations investigated in this study was not affected by road proximity as in the other two species, since traffic on Balkanic roads is comparatively low (although other explanations, such as differences in pollinator spectra are clearly possible, too). To fully understand how roads impact these plants, in the future it would be important to study how distance to natural grassland patches, traffic load intensity, dust deposition and position along roadsides interact to affect the reproductive success of Himantoglossum populations growing on roadside verges.

Together, our observations suggest that, while roadsides are suitable habitats for a large number of orchids, the immediate vicinity of roads could act as ecological traps (relatively poor quality habitats that attract a large number of individuals but have negative effects on their reproductive success; Schlaepfer, 2002). Although we found that roads have negative effect on reproductive success of Himantoglossum individuals, the fact that lizard orchids have significant and viable populations at roadsides suggest that roadside verges serve as refuges.

Since traditionally managed grasslands are disappearing, grassland plant species have a better chance of survival on road verges due to long-term adaptation to disturbances and light abundance, but their preservation depends on proper management (Tikka et al., 2000). Our result also reflect this, as we found that tree/shrub cover negatively affected reproductive success and number of flowers. The reason for this finding might lie in the high light intensities required by orchids to obtain sufficient energy for successful fruiting. Dominance shift from herbs to woody species can exclude orchids, thus disturbances such as mowing or grazing creates suitable conditions for them to persist and successfully reproduce (Janečkova et al., 2006, Sletvold et al., 2010, Slaviero et al., 2016, Kooijman et al., 2016). 


\section{Implications for management}

During planning and building new roads and reconstructing former roads, it should be avoided to create steep concrete retaining walls. Instead, gentler slopes are desirable to form a gradual transition to the natural landform. Terracing with rock outcrops can support this by facilitating the establishment of vegetation, creating microclimatic niches and stabilizing the structure of the cutting (Iuell et al., 2003). Conservation efforts directed to save Himantoglossum orchids might make significant contribution by creating new populations at roadsides on limestone or dolomite bedrock through seed sawing. On the one hand these populations could be easily approachable targets for enthusiasts aiming to photograph these enigmatic orchids. On the other hand, creation of these populations may relieve vulnerable, natural populations from damage (e.g. treading) accompanied with ecotourism. In management of roadside verges mowing is the most favorable method from the point of view of orchid conservation. On the contrary, we strongly oppose utilizing herbicides as roadside verge management, which is highly unfavorable for numerous threatened plant species and should be avoided for the sake of biodiversity conservation.

\section{Acknowlegements}

The authors are grateful to Zsófia Simon, Előd Búzás (Keszthely), Anna Farkas and Tünde Abonyi (Debrecen) for their assistance during field work. We would like to express our gratitude to Vladan Djordjević (Belgrade, Serbia) for his kind assistance. We are very grateful to Orsolya Vincze (University of Debrecen) for her professional comments and linguistic corrections on the earlier draft of this paper. We would like to express our thanks to our anonymous reviewers for their valuable comments and useful suggestions. This research was supported by the grants OTKA K108992 and the New National Excellence Program of the Hungarian Ministry of Human Capacities. JT was supported by the János Bolyai Research Scholarship of the Hungarian Academy of Sciences.

\section{Appendix A. Supplementary data}

Supplementary data to this article can be found online at goo.gl/m5ApiK 


\section{References}

Allem, A.C. 1997. Roadside habitats: a missing link in the conservation agenda. Environmentalist 17, 7-10.

Arditti, J., Ghani, A.K.A. 2000. Numerical and physical properties of orchid seeds and their biological implications. New Phytologist 145, 367-421.

Auestad, I., Rydgren, K., Austad, I. 2011. Road verges: potential refuges for declining grassland species despite remnant vegetation dynamics. Annales Botanici Fennici 48, 289-303.

Ballantyne, M., Pickering, C. 2011. Ecotourism as a threatening process for wild orchids, Journal of Ecotourism 11, 34-47.

Bateman, R.M., Molnár, V.A., Sramkó, G. 2017. In situ morphometric survey elucidates the evolutionary systematics of the Eurasian Himantoglossum clade (Orchidaceae: Orchidinae). PeerJ 5: e2893.

Bátori, Z., Körmöczi, L., Zalatnai, M., Erdős, L., Ódor, P., Tölgyesi, C., Margóczi, K., Torma, A., Gallé, R., Cseh, V., Török, P. 2016. River dikes in agricultural landscapes: The importance of secondary habitats in maintaining landscape-scale diversity. Wetlands $36,251-264$.

Bignal, E.M., McCracken, D.I. 1996. Low-intensity farming systems in the conservation of the countryside. Journal of Applied Ecology 33, 413-424.

Biró É., Bódis J., Nagy T., Tökölyi J., Molnár V. A. 2015. Honeybee (Apis mellifera) mediated increased reproductive success of a rare deceptive orchid. Applied Ecology and Environmental Research 13, 181-192.

Bochet, E., García-Fayos, P. 2004. Factors controlling vegetation establishment and water erosion on motorway slopes in Valencia, Spain. Restoration Ecology 12, 166-174.

Box, J. 1999. Nature conservation and post-industrial landscapes. Industrial Archaeology Review 21, 137-146.

Brandes, D. 1988. Die Vegetation gemähter Straßenränder im östlichen Niedersachsen. Tuexenia 8, 181-194.

Brandes, D. 1998a. Vegetation der Straßenränder Korfus. Vegetationsökologie von Habitatinseln und linearen Strukturen. Braunschweiger Geobot. Arb. 5, 247-262.

Brandes, D. 1998b. Flora und Vegetation der Straßenränder von Mallorca. Vegetationsökologie von Habitatinseln und linearen Strukturen. Braunschweiger Geobot. Arb. 5, 275-293. 
Bray, T.E., Wilson, B.L. 1992. Status of Platanthera praeclara Sheviak \& Bowles (western prairie fringed orchid) in the Platte River Valley in Nebraska from Hamilton to Garden counties.

Bzdon, G. 2009. Floristic diversity of gravel-pits of the Siedlce Plateau - an analysis of the flora. Annales UMCS, Biologia 64, 35-66.

Carey, P.D., Farrell, L. 2002. Himantoglossum hircinum (L.) Sprengel. Journal of Ecology 90, 206-218.

Claessens, J., Kleynen, J. 2011. The flower of the European orchid. Form and function. Claessens \& Kleynen, Geuelle. 440 pp.

Clifford, H.T. 1959. Seed dispersal by motor vehicles. Journal of Ecology 47, 311-315.

Coffin, A.W. 2007. From roadkill to road ecology: a review of the ecological effects of roads. Journal of transport Geography 15, 396-406.

Cousins, S.A. 2006. Plant species richness in midfield islets and road verges-the effect of landscape fragmentation. Biological Conservation 127, 500-509.

Curtis, J.T. 1946. Use of mowing in management of white ladyslipper. The Journal of Wildlife Management 10, 303-308.

Davis, B.N.K. 1979. Chalk and limestone quarries as wildlife habitats. Minerals and the Environment 1, 48-56.

Davison, A.W. 1971. The effects of de-icing salt on roadside verges. I. Soil and plant analysis. Journal of Applied Ecology 8, 555-561.

Deák, B., Tóthmérész, B., Valkó, O., Sudnik-Wojcikowska, B. Moysiyenko, I. I., Bragina, T. M., Apostolova, I., Dembicz, I., Bykov, N. I., Török, P. 2016a. Cultural monuments and nature conservation: a review of the role of kurgans in the conservation and restoration of steppe vegetation. Biodiversity and Conservation 25, 2473-2490.

Deák, B., Valkó, O., Török, P., Tóthmérész, B. 2016b. Factors threatening grassland specialist plants - A multi-proxy study on the vegetation of isolated grasslands. Biological Conservation 204, 255-262.

Deckers, B., Becker, P.D., Honnay, O., Hermy, M., Muys, B. 2005. Sunken roads as habitats for forest plant species in a dynamic agricultural landscape: effects of age and isolation. Journal of Biogeography 32, 99-109.

Djordjević, V., Tsiftsis, S., Lakušić, D., Jovanović, S., Stevanović, V. 2016. Factors affecting the distribution and abundance of orchids in grasslands and herbaceous wetlands. Systematics and Biodiversity 14, 355-370. 
Duchoň, M. 2012. Nové lokality druhu Himantoglossum adriaticum (Orchidaceae) v horskej skupine Drieňova v južnej časti Strážovských vrchov. Bulletin Slovenskej Botanickej Spoločnosti 34, 151-157.

Ehmke, W. 2005. Die Orchideen im hessischen Westtaunus. Geobot. Kolloq. 18, 9-16.

Eriksson, O., Cousins, S.A., Bruun, H.H. 2002. Land-use history and fragmentation of traditionally managed grasslands in Scandinavia. Journal of Vegetation Science 13, 743748.

Esfeld, K., Hensen, I., Wesche, K., Jakob, S.S., Tischew, S., Blattner, F.R. 2008. Molecular data indicate multiple independent colonizations of former lignite mining areas in Eastern Germany by Epipactis palustris (Orchidaceae). Biodiversity and Conservation 17, 2441.

European Union, 1992. Council Directive 92/43/EEC on the Conservation of Natural Habitats and of Wild Fauna and Flora. European Commission, Brussel, Belgium.

Farmer, A.M. 1993. The effects of dust on vegetation a review. Environmental pollution 79, $63-75$.

Federici, A., Serpieri, A. 1868. Saggio di una Flora dell'agro urbinate ed epoca della fioritura di molte piante. Bullettino Metereologico di Urbino 2, 48-56.

Gardiner, T., Vaughan, A. 2009. Scrub clearance and soil disturbance increases bee orchid Ophrys apifera frequency in calcareous grassland at Norton Heath roadside verge, Essex, England. Conservation Evidence 6: 39.

Godefroid, S. 1999. Study of the roadside vegetation in the Walloon region (South Belgium) and in particular in the Upper Ardennes: phytosociology, ecology, pedology. Acta Botanica Gallica 146, 291-292.

Good, R., 1936. On the distribution of lizard orchid, Himantoglossum hircinum Koch. New Phytologist 35, 142-170.

Grant, C.D., Koch, J. 2003. Orchid species succession in rehabilitated bauxite mines in Western Australia. Australian Journal of Botany 51, 453-457.

Greenberg, C.H., Crownover, S.H., Gordon, D.R. 1997. Roadside soils: a corridor for invasion of xeric shrub by nonindigenous plants. Natural Areas Journal 17: 99-109.

Greenwood, E.F., Gemmell, R.P. 1978. Derelict industrial land as a habitat for rare plants in S. Lancs.(vc 59) and W. Lancs.(vc 60). Watsonia 12, 33-40.

Harrington, J.A. 1994. Roadside landscapes prairie species take hold in midwest rights-ofway. Ecological Restoration 12, 8-15.

Harrison, X.A. 2014. Using observation-level random effects to model overdispersion in count data in ecology and evolution. PeerJ 2: e616. 
Heneberg, P., Bogusch, P., Řezáč, M. 2017. Roadside verges can support spontaneous establishment of steppe-like habitats hosting diverse assemblages of bees and wasps (Hymenoptera: Aculeata) in an intensively cultivated central European landscape. Biodiversity \& Conservation 26, 843-864.

Hogbin, P.M., Ayre D.J., Whelan R.J. 1998. Genetic variation and reproductive success of road verge populations of the rare shrub Grevillea barklyana (Proteaceae). Heredity 80, 180-186.

Holliday, R.J., Johnson, M.S. 1979. The contribution of derelict mineral and industrial sites to the conservation of rare plants in the United Kingdom. Minerals and the Environment 1, 17.

Hopwood, J. L. 2008. The contribution of roadside grassland restorations to native bee conservation. Biological Conservation 141, 2632-2640.

Hovd, H., Skogen, A. 2005. Plant species in arable field margins and road verges of central Norway. Agriculture, Ecosystems and Environment 110, 257-265.

Huhta, A.P., Rautio, P. 2007. A case with blue gentian blues: roadside-cutters creating neo grasslands as refugia for endangered Gentianella campestris. Nordic Journal of Botany $25,372-379$.

Hussey, B.M.J., 1999. The flora roads survey volunteer recording of roadside vegetation in Western Australia. In: Saunders, D.A. (Ed.), Nature Conservation 4: The Role of Networks. Surrey Beatty \& Sons Propriety, Chipping Norton, Australia, pp. 41-48.

Iuell, B., Bekker, G.J., Cuperus, R., Dufek, J., Fry, G., Hicks, C., Hlaváč, V., Keller, V.B., Rosell, C., Sangwine, T., Tørsløv, N., Wandall, Le Maire, B. (Eds.) 2003. Wildlife and Traffic: A European Handbook for Identifying Conflicts and Designing Solutions.

Jakobsson, A., Ågren, J. 2014. Distance to semi-natural grassland influences seed production of insect-pollinated herbs. Oecologia 175, 199-208.

Janečková, P., Wotavová, K., Schödelbauerová, I., Jersáková, J., Kindlmann, P. 2006. Relative effects of management and environmental conditions on performance and survival of populations of a terrestrial orchid, Dactylorhiza majalis. Biological Conservation 129, 40-49.

Jennersten, O.L.A. 1988. Pollination in Dianthus deltoides (Caryophyllaceae): effects of habitat fragmentation on visitation and seed set. Conservation Biology 2, 359-366.

Jersáková, J., Malinová, T. 2007. Spatial aspects of seed dispersal and seedling recruitment in orchids. New Phytologist 176, 237-241. 
Jurkiewicz, A., Turnau, K., Mesjasz-Przybyłowicz, J., Przybyłowicz, W., Godzik, B. 2001. Heavy metal localisation in mycorrhizas of Epipactis atrorubens (Hoffm.) Besser (Orchidaceae) from zinc mine tailings. Protoplasma 218, 117-124.

Kallioniemi, E., Åström, J., Rusch, G. M., Dahle, S., Åström, S., Gjershaug, J. O. 2017. Local resources, linear elements and mass-flowering crops determine bumblebee occurrences in moderately intensified farmlands. Agriculture, Ecosystems \& Environment 239, 90-100.

Känzig-Schoch, U. 2006. Häufigkeit und Verbreitung von Himantoglossum hircinum im Kanton Bern. Botanica Helvetica 116, 91-118.

Kelcey, J.G. 1984. Industrial development and the conservation of vascular plants, with special reference to Britain. Environmental Conservation 11, 235-245

Klaver, J.M.I. 2011. Himantoglossum adriaticum H. Baumann in Central-East Italy (PesaroUrbino, Marche) and FFH-Directive 92/43/EEC. Journal Europäischer Orchideen 43, $590-602$.

Kooijman, A.M., Bruin, C.J.W., van de Craats, A., Grootjans, A.P., Oostermeijer, J.G.B., Scholten, R., Sharudin, R. 2016. Past and future of the EU-habitat directive species Liparis loeselii in relation to landscape and habitat dynamics in SW-Texel, the Netherlands. Science of the Total Environment 568, 107-117.

Krauss, J., Bommarco, R., Guardiola, M., Heikkinen, R.K., Helm, A., Kuussaari, M., Lindborg, R., Öckinger, E., Pärtel, M., Pino, J., Pöyry, J., Raatikainen, K.M., Sang, A., Stefanescu, C., Teder, T., Zobel, M., Steffan-Dewenter, I. 2010. Habitat fragmentation causes immediate and time $\square$ delayed biodiversity loss at different trophic levels. Ecology Letters 13, 597-605.

Lamont, B.B., Connell, S.W., Bergl, S.M. 1991. Seed bank and population dynamics of Banksia cuneata: the role of time, fire, and moisture. Botanical Gazette 152, 114-122.

Lamont, B.B., Rees, R.G., Witkowski, E.T.F., Whitten, V.A. 1994. Comparative size, fecundity and ecophysiology of roadside plants of Banksia hookeriana. Journal of Applied Ecology 31, 137-144.

Lamont, B.B., Written, V.A., Witkowski, E.T.F., Rees, R.G., Enright, N.J. 1994. Regional and local (road verge) effects on size and fecundity in Banksia menziesii. Australian Journal of Ecology 19, 197-205.

Lamont, B.B., Klinkhamer, P.G., Witkowski, E.T.F. 1993. Population fragmentation may reduce fertility to zero in Banksia goodii - a demonstration of the Allee effect. Oecologia 94, 446-450. 
Löki, V., Tökölyi, J., Süveges K., Lovas-Kiss Á., Hürkan K., Sramkó G., Molnár V. A. 2015. The orchid flora of Turkish graveyards: a comprehensive survey. Willdenowia 45, 231243.

Lundholm, J.T., Richardson, P.J. 2010. Mini-review: Habitat analogues for reconciliation ecology in urban and industrial environments. Journal of Applied Ecology 47, 966-975.

Molnár V., A., Takács, A., Mizsei, E., Löki, V., Barina, Z., Sramkó, G., Tökölyi J. 2017. Religious differences affect orchid diversity of Albanian graveyards. Pakistan Journal of Botany 49, 289-303.

Muñoz, P.T., Torres, F.P., Megías, A.G. 2014. Effects of roads on insects: a review. Biodiversity and Conservation 24, 659-682.

Nascimbene, J., Zottini, M., Ivan, D., Casagrande, V., Marini, L. 2016. Do vineyards in contrasting landscapes contribute to conserve plant species of dry calcareous grasslands? Science of the Total Environment 545: 244-249.

Ndiokwere, C. L. 1984. A study of heavy metal pollution from motor vehicle emissions and its effect on roadside soil, vegetation and crops in Nigeria. Environmental Pollution Series B, Chemical and Physical 7, 35-42.

Neto, C., Cardigos, P., Oliveira, S.C., Zêzere, J.L. 2017. Floristic and vegetation successional processes within landslides in a Mediterranean environment. Science of the Total Environment 574, 969-981.

Perring, F.H. 1969. The botanical importance of roadside verges. In: In: Way, J.M., (ed.) Road verges - their function and management. Abbots Ripton, The Nature Conservancy, pp. 4-7.

Pykälä, J., Luoto, M., Heikkinen, R.K., Kontula, T. 2005. Plant species richness and persistence of rare plants in abandoned semi-natural grasslands in northern Europe. Basic and Applied Ecology 6, 25-33.

R Core Team 2016. The R Project for for statistical computing. Vienna: R Foundation for Statistical Computing. https://www.r-project.org/ (Accessed 17/02/2017)

Rai, I.D., Adhikari, B.S., Rawat, G.S. 2010. A unique patch of timberline ecotone with three species of Lady's slipper orchids in Garhwal Himalaya, India. Journal of Threatened Taxa 2, 766-769.

Ratcliffe, D.A. 1974. Ecological effects of mineral exploitation in the United Kingdom and their significance to nature conservation. Proceedings of the Royal Society of London A: Mathematical, Physical and Engineering Sciences 339, 355-372. 
Ross, S.M. 1986. Vegetation change on highway verges in south-east Scotland. Journal of Biogeography 13, 109-117.

Ryser, P., Sauder, W. R. 2006. Effects of heavy-metal-contaminated soil on growth, phenology and biomass turnover of Hieracium piloselloides. Environmental Pollution $140,52-61$.

Saikkonen, K., Koivunen, S., Vuorisalo, T., Mutikainen, P. 1998. Interactive effects of pollination and heavy metals on resource allocation in Potentilla anserina L. Ecology 79, 1620-1629.

Schlaepfer, M.A., Runge, M.C., Sherman, P.W. 2002. Ecological and evolutionary traps. Trends in Ecology \& Evolution 17, 474-480.

Shefferson, R.P., Kull, T., Tali, K. 2008. Mycorrhizal interactions of orchids colonizing Estonian mine tailings hills. American Journal of Botany 95, 156-164.

Slaviero, A., Del Vecchio, S., Pierce, S., Fantinato, E., Buffa, G. 2016. Plant community attributes affect dry grassland orchid establishment. Plant Ecology 217, 1533-1543.

Sletvold, N., Øien, D.I., Moen, A. 2010. Long-term influence of mowing on population dynamics in the rare orchid Dactylorhiza lapponica: the importance of recruitment and seed production. Biological Conservation 143, 747-755.

Smith, P.H., Cross, S. 2016. Effect of mowing regime on abundance of green-winged orchid Anacamptis morio on coastal grassland in Merseyside, England.

Sonkoly, J., E Vojtkó, A., Tökölyi, J., Török, P., Sramkó, G., Illyés, Z., Molnár, V. 2016. Higher seed number compensates for lower fruit set in deceptive orchids. Journal of Ecology 104, 343-351.

Sramkó, G., Molnár, A., Hawkins, J.A., Bateman, R.M. 2014. Molecular phylogeny and evolutionary history of the Eurasiatic orchid genus Himantoglossum sl. (Orchidaceae). Annals of Botany 114, 1609-1626.

Sun, M. 1997. Genetic diversity in three colonizing orchids with contrasting mating systems. American Journal of Botany 84, 224-224.

Swarts N. D., Dixon K. W. 2009. Terrestrial orchid conservation in the age of extinction. Annals of Botany 104, 543-556.

Tikka, P.M., Högmander, H., Koski, P.S. 2001. Road and railway verges serve as dispersal corridors for grassland plants. Landscape Ecology 16, 659-666.

Tikka, P.M., Koski, P.S., Kivelä, R.A., Kuitunen, M.T. 2000. Can grassland plant communities be preserved on road and railway verges? Applied Vegetation Science 3, $25-$ 32. 
Tilman, D., Fargione, J., Wolff, B., D'Antonio, C., Dobson, A., Howarth, R., Schindler, D., Schlesinger, W.H., Simberloff, D., Swackhamer, D. 2001. Forecasting agriculturally driven global environmental change. Science 292, 281-284.

Truscott, A.M., Palmer, S.C.F., McGowan, G.M., Cape, J.N., Smart, S. 2005. Vegetation composition of roadside verges in Scotland: the effects of nitrogen deposition, disturbance and management. Environmental Pollution 136, 109-118.

Turrill, W.B. 1932. On the Flora of the Nearer East: XI. A contribution to the flora of Albania. Bulletin of miscellaneous information (Royal Botanic Gardens, Kew) 1932, 193 198.

Vasconcelos, P.B., Araújo, G.M., Bruna, E.M. 2014. The role of roadsides in conserving Cerrado plant diversity. Biodiversity \& Conservation 23, 3035-3050.

Waterman, R.J., Bidartondo, M.I. 2008. Deception above, deception below: linking pollination and mycorrhizal biology of orchids. Journal of Experimental Botany 59, 10851096.

Watson, V.J., Rice, P.M., Monnig, E.C. 1989. Environmental fate of picloram used for roadside weed control. Journal of Environmental Quality 18, 198-205.

Way, J.M. 1970. Roads and the conservation of wildlife. J. Inst. Highway Engrs, 17, 5-11.

Way, J.M. 1977. Roadside verges and conservation in Britain: a review. Biological Conservation $12,65-74$.

Woch, M.W., Radwanska, M., Stefanowitz, A.M. 2013. Flora of spoil heaps after hard coal mining in Trzebinia (southern Poland): effect of substratum properties. Acta Botanica Croatica 72, 237-256.

Young, A., Boyle, T., Brown, T. 1996. The population genetic consequences of habitat fragmentation for plants. Trends in Ecology \& Evolution 11, 413-418.

Zahariev, D., 2014. Favorable impact of road infrastructure onthe distribution and abundance of populations of Himantoglossum caprinum (M. Bieb.) Spreng. in Shumensko plato Protected area (BG0000382) and Rishki prohod Protected area (BG0000149) from the European ecological network Natura 2000. Acta Scientifica Naturalis 1, 166-174. 